Mlekel-Iron-Aluatnius Shape Mecory Alloys with Icoroved Propert les by Rapid Soltdifteation

P. Johansson, J. LIU and S. Savage

Swedish Institute for Motals Research

Orottning Kristinas vig 48

S-114 28 Stockholm, Swoden

Repidly solidifled alcro-wires (- $150 \mathrm{\mu l}$ dla) and ribbons ( $15 \mathrm{kn}$ ehick) have Deen produced by direct casting and wit spinning techniques respectively. The

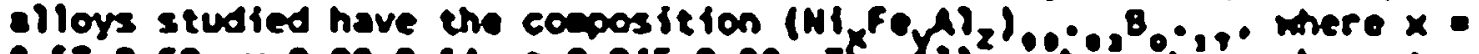
0.57-0.62: y=0.09-0.14, 2=0.245-0.29. The liloys nave beten chorecterized by theral anslysis (OSC). lectricol resistance mesurement. tensile testing and alcrostructural enalysis.

A range of alloy compostitions have been produced. All of thea exh ibit the shape memory offect (shape recovery on hesting. after cold defornstion) llthough by OSC the aartensite transtorastion is not clearly seen in all the -lloys. Measurement of electrical restatence is the cost senstive way co follow the transforations in these alloys. The difference in resistance. at the sace temperature, can be as high as 0.245 pon for heating and cooling cycles. The eaximun frecture stress obtolned in an es-case wire is - 1450 mpo. with elongation to fracture in the range 14-18\%.

Estinated values of pseudo-elasticliy are as high as i4t. Microstructural anelysis leads to the conclusion thot the rlbbons experienco a higher solidypleation rote then the wires, which mey explein the somewhat different aartenstte properties.

\title{
Introduction
}

shape becory alloys (SMi's) have any potentfol opplications in functional oreas for control systees, robotics. electronles. telecomounteations and bioondiclne. However. to produce the olloys in o sultable forn (wire or thin stripl by conventional aetal working processes is often difficult due to the poor morkablitity of these alloys. Rapld solfdification technology (RST) offers - conventent and econofical alternative way to produce near net shape asterials. The rapidiy solidiffed shape necory alloys usually have a high area/volum ratto ahteh enhances hejt transfor to and froe the asterials. It has Dem show (I) that wetsestable nickel-pich a eartensite (A') cotoined by water quenching from the p-phase field at high temperature undergoes a theracelastic artenstie transforastion $\left(\beta^{\prime}+\beta\right)$ ot elevated temperatures. Boading to a shape waory effect. However. conventionally cast MIAl compound does not exhiblt an appreclable tenstle elongation at room teaporsture and hence the shape recovery has been IInteod to a smell bending stroln $P\left(0 \mid d(2)\right.$. NI,Al $\left(\gamma^{\prime}\right)$ and $\gamma^{\prime}+A$ compounds in the NI-Fo-Al systen with good ductlitey and hioh serength have been obtained by rapid solifification $(3,1)$. Furukawa at al (B) have Investlgeted of the Mi-Fe-Al systen which shows areat potentiol for development of SMA's due to extension of the $\beta$ - end $\beta^{\prime}$-phese fleld by RST.

It was reported $(5)$. that the iransformation between $\beta^{\circ}$ and $\beta$ occurs reversibIy in a rather narrow teeperature range of about $80 \mathrm{~K}$. Addtition of 0.17 ats 8

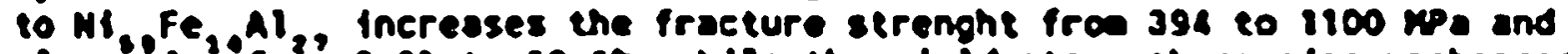
elongition fró 2.85 to 18.18. Wile the yleld strength rewains unchanged. 
The reason for the ieprovenent of dueflifty and strength is probebly a conble ned effect of groin size refinement and suppression of the dwvilopent of en ordered structure conbined with groin boundary segregation. Significant deterioration of the shape necory effect (SME) and ductility in the vicinity of $600 \mathrm{~K}$ was found to be due to the proolpltetion of $\mathrm{NI}, \mathrm{Al}$ and $\mathrm{NI}, \mathrm{Al},{ }^{\circ}$

The present work olas ot further dovelopment of these newly lound Mi-Fe-Albese shape aemory alloys by RST. The products were chorocter lzed by aterostructure enslysis. tensile testing and irensforation tecpereture ceasurement by differentiol imeral calorientry (OSC) and electrical resistance ceasurecent.

\section{Experinentel work}

The compostetons of the rapidly soltdifled rlboons and wires are show in Table 1 produced by "chtll block molt apinning" and "In rotating water molt epinning" (b) respoctively.

\begin{tabular}{|llllll|}
\hline AlIOY & NI & Fe & AI & B \\
\hline 1 & 56.90 & 13.96 & 28.95 & 0.17 \\
2 & 61.66 & 13.90 & 24.17 & 0.17 \\
3 & 61.89 & 0.98 & 28.95 & 0.17 \\
1 & 59 & 18 & 27 & \\
5 & 58.90 & 13.90 & 26.95 & 0.17 \\
\hline
\end{tabular}

Toble 1. Invest looted alloys. Consent ott.

Mickel. alwintue, Iron and boron wre wighed out for eveh alloy and induction nelted under en argan atonsohere in en elumina cructole. The nolten antel was sucked up in a slilea tube and ollamd to solidify. After cooling in water. and removing the silica tube 8 aleater rods mre colelned. These were cleaned in alcohol, and drled in hot afr and cut up into saell pieces for the wire cesting and melt spinning exper faents. Hires of - 180 un dia.. and ribbons of $\sim 78 \mathrm{un}$ thickness were produced (6).

Sanples for optleol miteroscopy wore prepored by convent lonal mounting in therwosetting rosin, orfinding. pollshing and chewical etching. Tensile testing was carried oul et atrain rate of $4.18 .10^{\circ} \mathrm{s}^{-1}$ at roon teeperature. Offferential thermal calor leetry (DSC) was parforeed on -15 a seaples at a cooling/heating rate of $10 \mathrm{k} / \mathrm{s}$. Electric resistivity wasureents were per. forwed on es-cest and as cast and met ireoted saples.

Resuits and discussion

DSC

All the alloys show atsible shope recovery on heating after cold deforaation. However. only ino of the rboons (allors $A$ and 5 ) shom packs on the osecurves. Indicoting a phase transforation. The difference betmen these two riboons is only 0.18 at 8 boron addition. The eeasured irensforeation terperetures correlete $\mathrm{w} / 1 \mathrm{w}$ ith the alcrostructure shom in Fioure 1. With the predicted trensforaction temperstures in olnd (5) alloy no. 3 ought to show artensite phese but didn't. Mo Osc-paak mas observed, netiher below or sbove 
roon tempersture. In splte of the lect thot tests with different inictness of the ribbon were dome. The concluston of ehis is that without cerefully noted conditions during repid solidiffeation. It is hand to predtet im shape of the mtastable phase-dlegras. Also alloy no. 2 wos predicted to shon osc peaks but didn't.

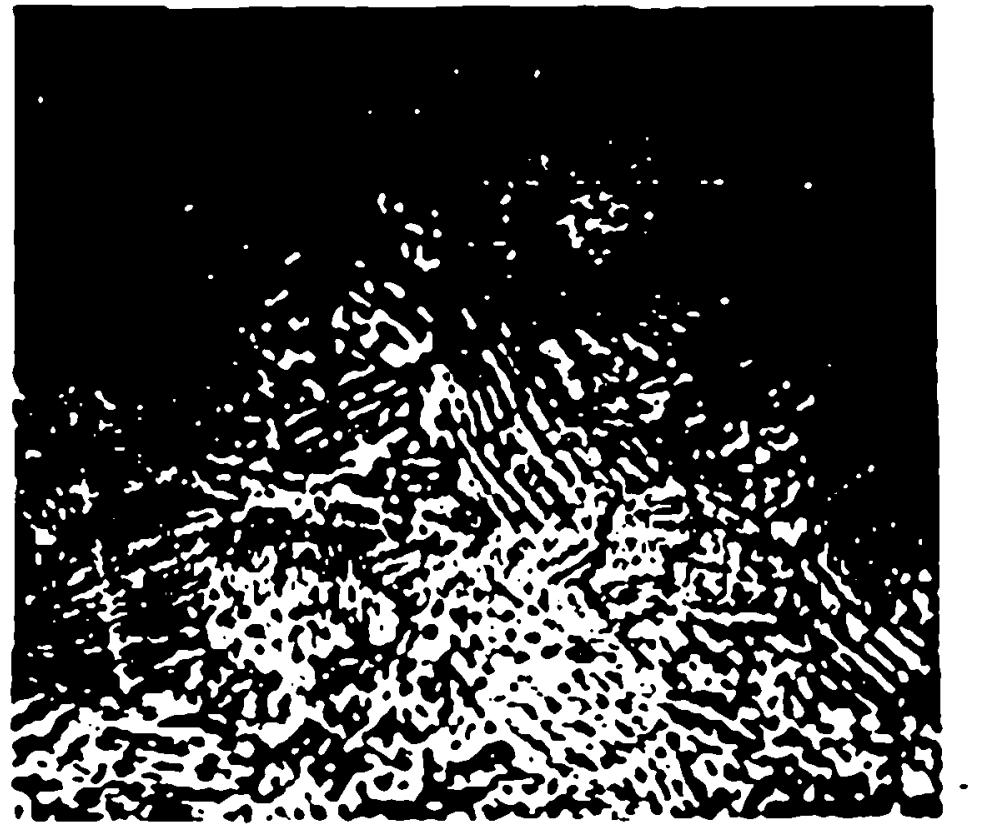

Figure 1. Riboon of alloy No. S.

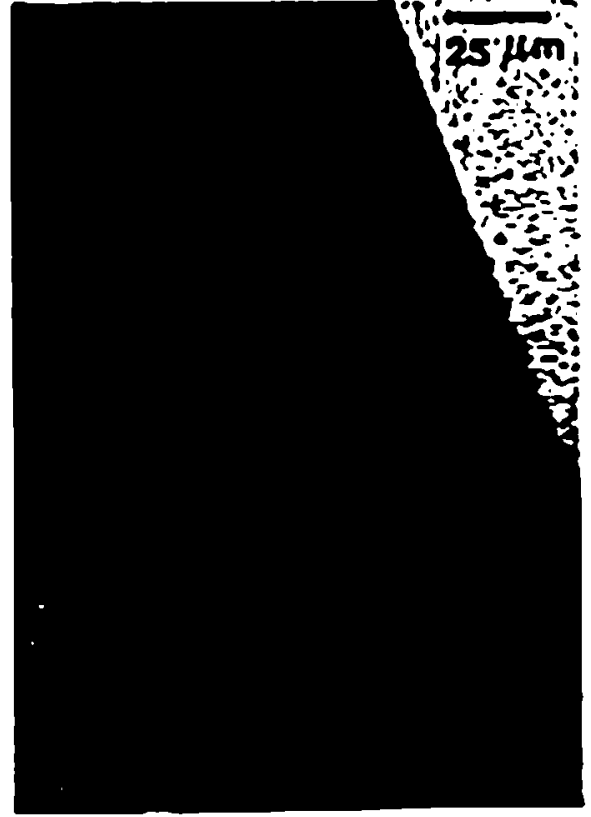

Figure 2. Mire of alloy No. 5.

the rapidly solldifled wires show a completely different bohavlour. They show no peaks at all in the DSC. A typical mierostructure is shown in Floure 2. Alloys with no OSC poaks in ribbon form ore not expected to show peaks for the wire. For the two elloys for mich peaks mere obtained in the ribbon very slight peaks can be seen by careful exeelnotion. The conclusion wich way be dram is that a nigh cooling rate is the doelnant factor for obtaining wertensite in inese alloys.

\section{Heot ereateent}

After annealing $r$ fboons of alloy no. B for 1 hour a DSC-run was carried out whtch gave the results shown in flgure $J$ and 4 . The aertenslte to usstentto peok transition seaperature $A$ is lowpred fron $125 K$ in the as quenched state to $380 \mathrm{~K}$ after the hest ireatent at 62JK. but then ralsed to $105 \mathrm{~K}$ ofter ennealing of 80Jx.

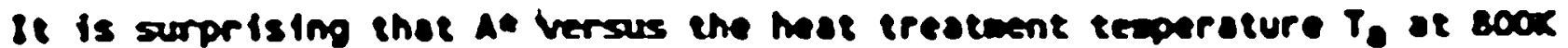
diverge from provlously reported results (5). The alt dependence on $T_{a}$ shours thet the volum of iransforation is roduced after heat ireatent, and decreases with incressing annealing temporsture due to stobllizetion of equilforium pheses. Thermal cycling between 300K and s00K was carrled out with wire of alloy no. 4 to find out 11 this can force a peak to oppear. without result.

\section{Metallography}

The resules from apetcol elcroscopy are given in Tables 2 and 3. In Figure I the presence of eartenstie in the riboon of elloy no. S Is clearly seen. The sewe phase is coserved in ribbons of olloy no. A. 


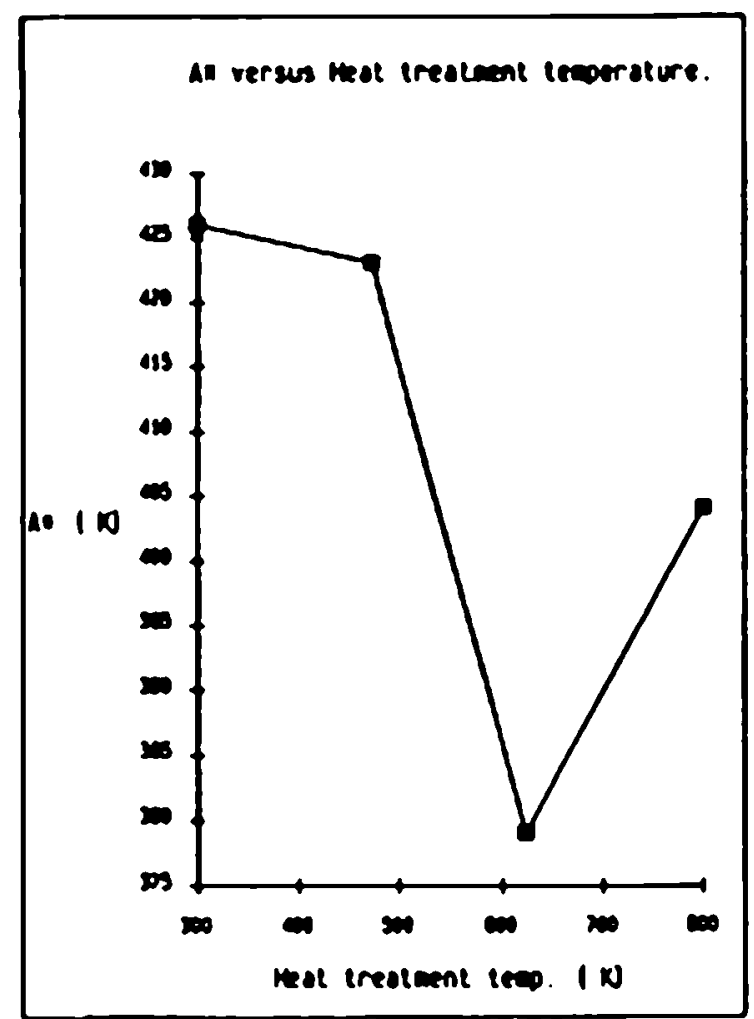

Figure 3. Ribbon of Illoy No. 5. Hoat treated for 1 hour.

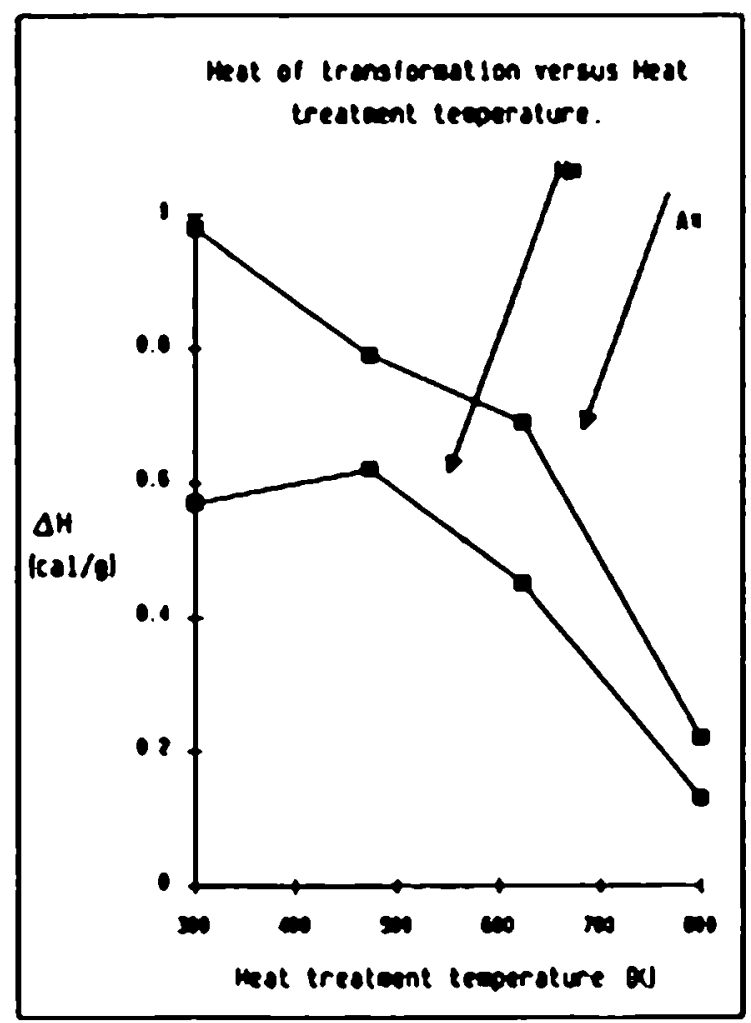

Figure 1. Ribbon of alloy No. 5. Heat treated for 1 hour.

$M *$ and $A *$ are austenite to martensite and marteniste to oustentte peak transition temperatures respectively.

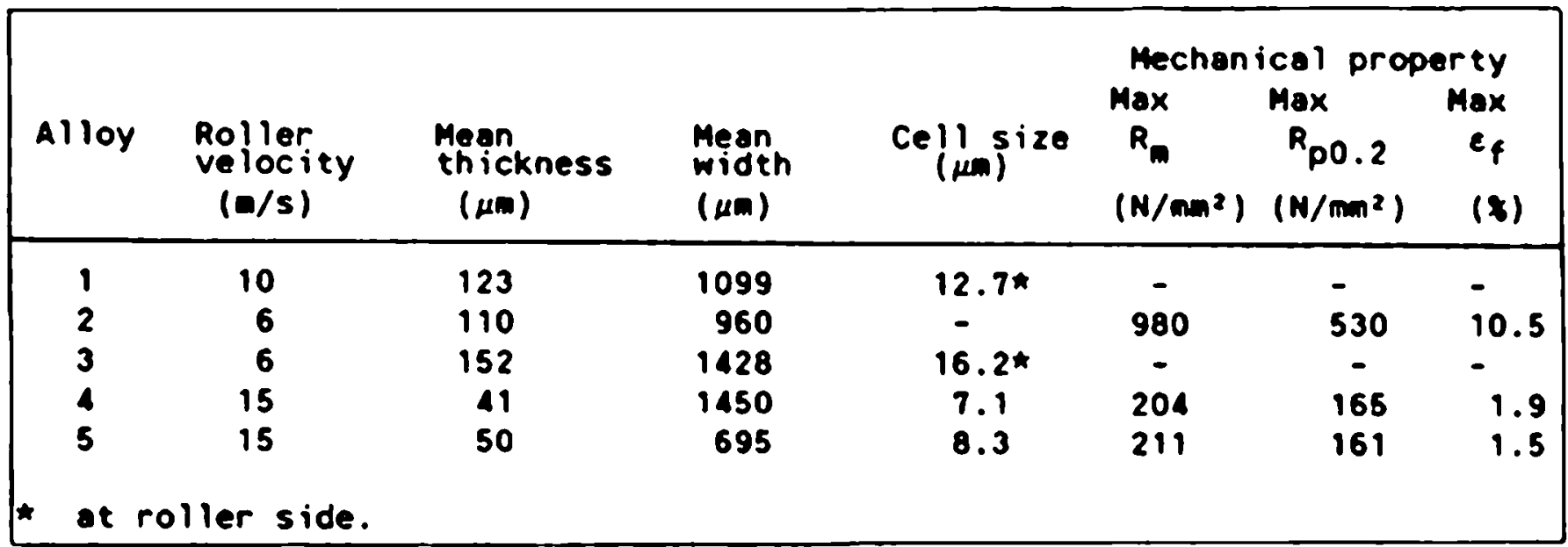

Table 2. Experimental conditions and properties of rapidly solidified direcely cast ribbons.

In Figure 5 a schematic relationship between the austenite to martensite transitton start temperature $M_{s}$ and $A 7$-content is shom. The eicrosegregation in the wires results in a microstructure that consists of primary solidifted dendrites and secondary solidified phase with increased Al-content, as can be seen in Figure 2. This gives $r$ ise to a range of transformation temperatures. and as a result a poor SHE is obtained. 


\begin{tabular}{|c|c|c|c|c|c|}
\hline Alloy & 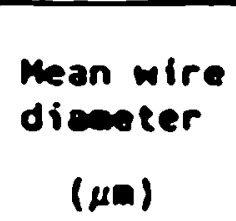 & $\begin{array}{c}\text { Mean secondery } \\
\text { dendrtte } \\
\text { orm spacing } \\
\text { ( } \mu(n)\end{array}$ & $\begin{array}{l}\text { 'Mechon } \\
\text { Max } \\
R_{\text {a }} \\
\left(\mathrm{N} / \mathrm{m}^{2}\right)\end{array}$ & $\begin{array}{l}\text { a) propert } \\
\text { Max } \\
\text { Rpo. }_{(\text {p/ing) }}\end{array}$ & $\begin{array}{l}y_{\text {Max }} \\
e_{f} \\
\left(f^{\prime}\right)\end{array}$ \\
\hline 1 & 175 & 3.4 & - & - & - \\
\hline 2 & 179 & 1.8 & 1015 & 279 & 13.3 \\
\hline 3 & 243 & 3.0 & - & - & - \\
\hline 4 & 118 & 2.3 & 526 & 422 & 4.4 \\
\hline b & 183 & 2.4 & 1448 & 519 & 18 \\
\hline
\end{tabular}

Table 3. Properties of rapidly solidifted directly cast atcro-wires.

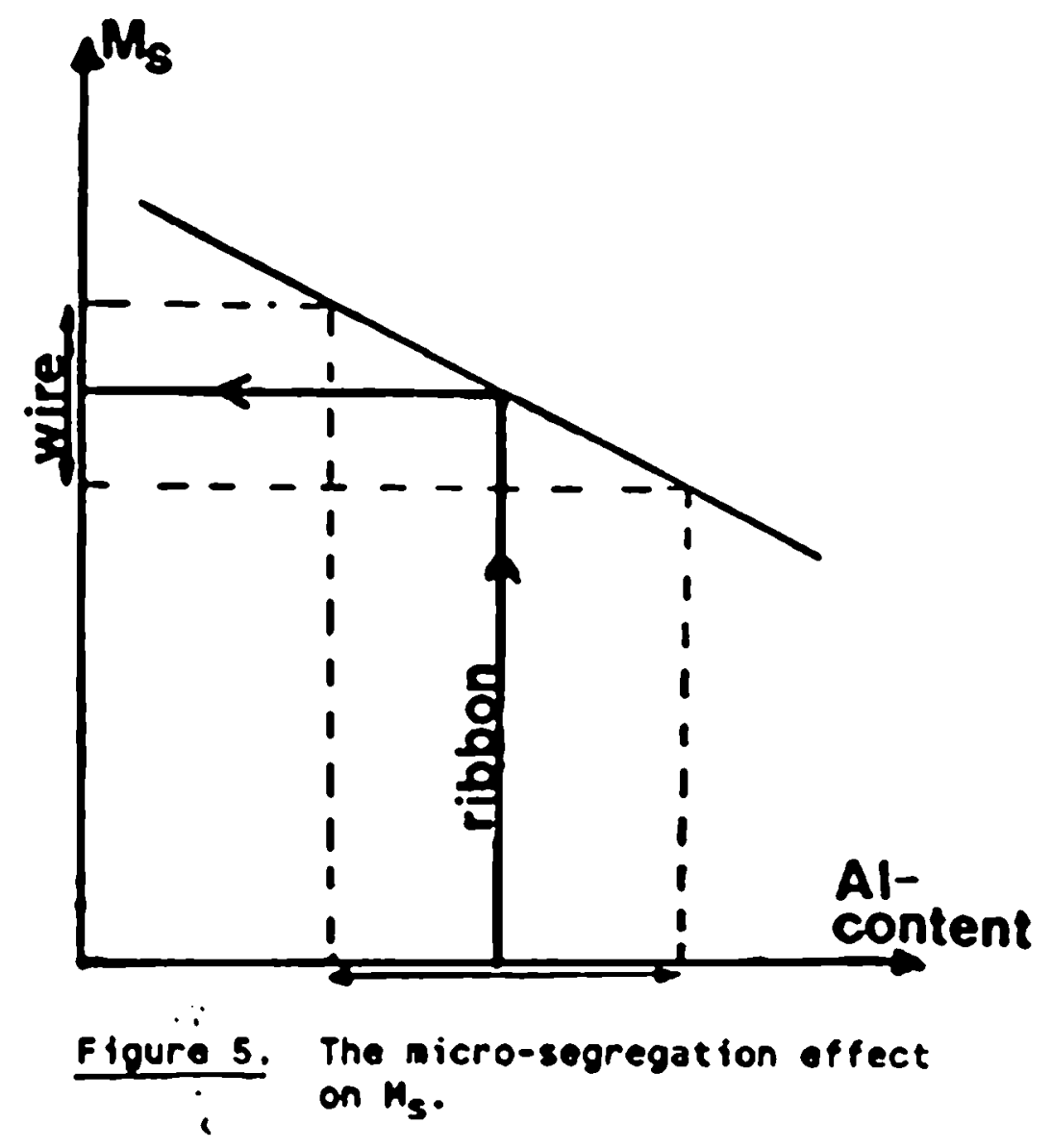

By measurement of the secondary dendrtte or spacing or cell size it is possible to calculate cooling rates of the as-quenched ribbons. The cooling rate in this process is normally in the range of $10^{\circ}-10^{2} \mathrm{~K} / \mathrm{s}$ (7). The secondery dendrite are spacings in the wires give cooling rate of -104 $\mathrm{K} / \mathrm{s}(8)$ wich is somphat lower than for ribbons. To obtain cooling rates in wire comparable with ribbon, wich are needed in order to obtain the sane microstructure, the heat transfer has to be improved, for example, by casting wire of snaller diameter. 
242

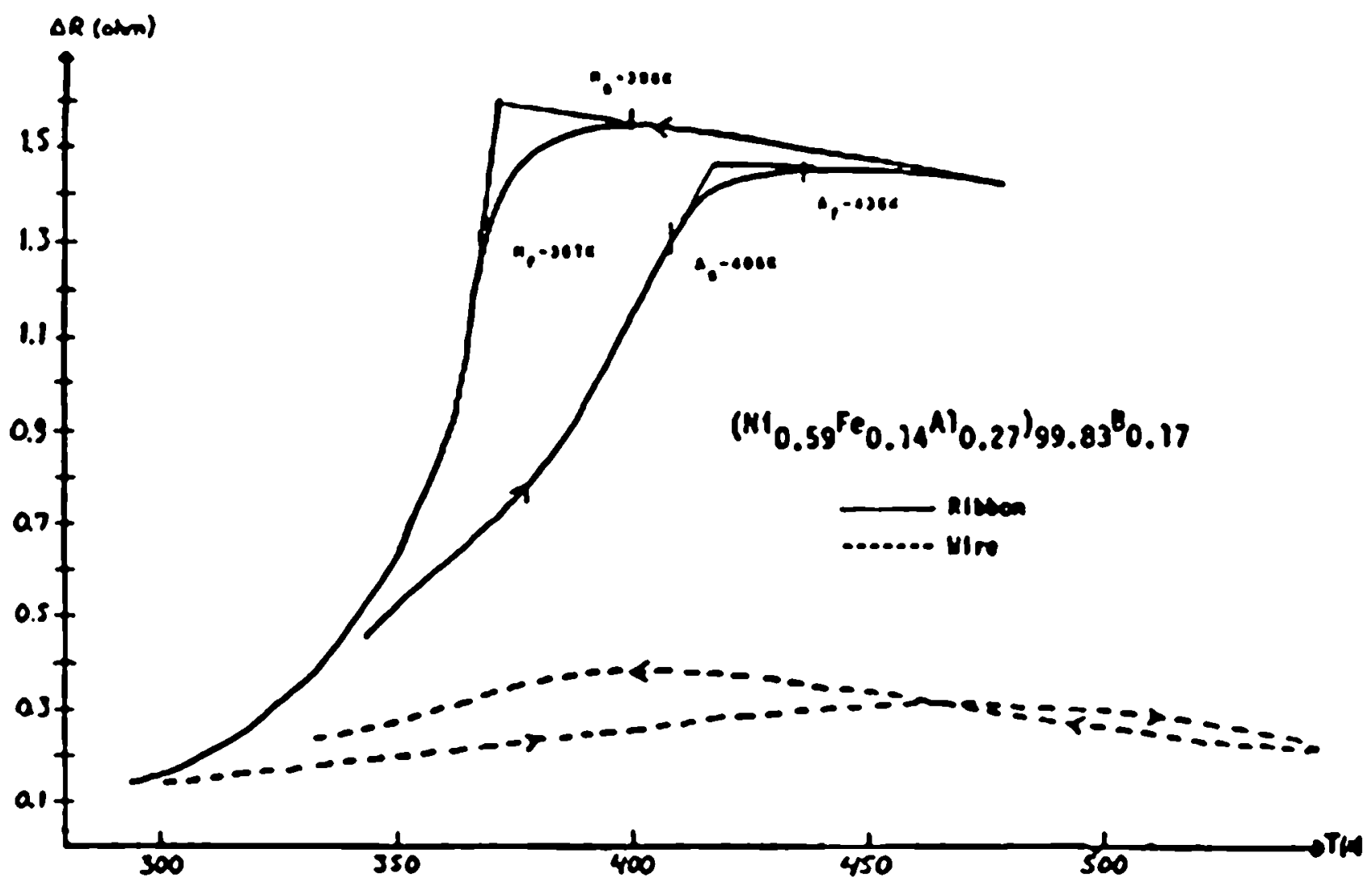

Figure 6. Resistance measurements. Interpretation of transformation.

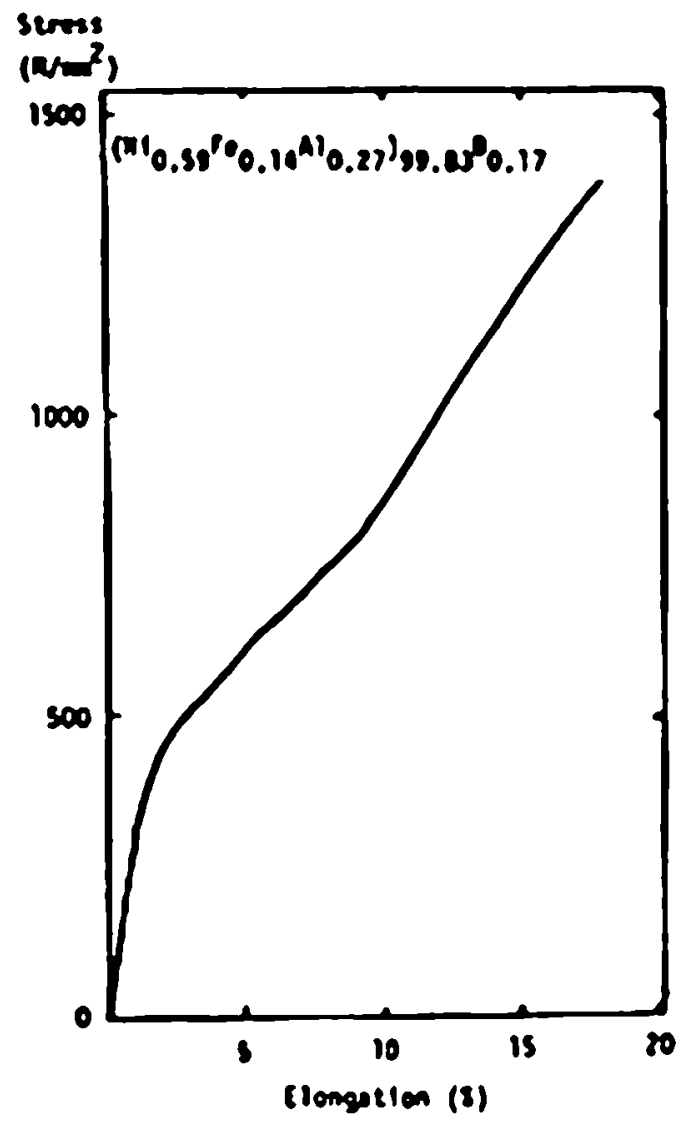

Figure 7. Stress - Strain diagram. 
Reststence meosurements

Resistance versus temperature results for ribbon and wire are given in Fig.6. For 1 lloy $m_{0}$. A, it is possible to find $M_{f}=400 K$ and $M_{f}=382 K$ (consistent with OSC results which givas $M_{s}=399 K$ and $\left.A_{f}=379 K\right)$. On heating it is much more difficult to observe accuracely but gives values of $A_{s} m 429 K$ and $A_{f} m$ isiK (DSC results gives $A_{s}=410 K$ and $\left.A_{f}=136 K\right)$. The agreement between these results is encoureging. For $r$ ibbon of alloy no.s it is even wore encouraging with $M_{s}=396 K$ Mf-367K. A $A_{s} 106 K$ and $A_{f}=436 K$. (DSC gives 397, 374, 404 and 441K

respectively). To interpretate the curves help is taken from the OSC-results. In figure 6 te is shown how $M_{s}$. Mg. $A_{s}$ and $A_{f}$ hove been obteined from the heating and cooling curves. In this ligure wire and riboon are compred. The difference in resistance, ot the sane temperature, can be as high os 0.245 uon for heating and cooling cycles.

\section{Tenstle testing}

The tensile cesting results are shown in Tables 2 and 3 for alloys no 2. 4 and 5. These results moke it clear that the wires and ribbons found ductile by a simple bend test (bending the rtboon or wire 1800 . to give a strain of 1) - lso give high tensile strengths $a .9$. For wires and ribbons of alioy no. 2 and wires of alloy no. 5. A lerge scatier of tenstie results was observed which is - result of varlations in thickness of samples and the production conditions (for exanple roughness of the ribbon surface). All ribbons and wires mere tested in the es-produced condition.

The highest mechanical testing results are those shown in Figure 7. obtained from wire of alloy no. 5. A fracture elongation as high as 18 combined with 1448 Ha ultinate tenstle strength ore comarable to results in (5). A value for recoverable strain (6), is estimoted at about 14x.

\section{Conclusions}

The mechanteal and shape menory properties show signiflcent varfations in terns of small differences in alloy content, cooling rate and microstructure. The composttional dependence of rapidly solidifted structures in the Ni-Fe-Al system can not be estimated without careful evaluation of the production process parancters. e.g. cooling rate.

Mtcrosegregation in the. wires results in a microstructure that consists of primary soltdifted dendrites and secondary solfdified phase with increased Al-content. As a result pf this a poor SHE is obtained. With further developwent of the processing techniques for these elloys. on the basis of the results shown. It is expected thet wires and ribbons with good combinations of achanical properties and SuE can be produced.

\section{Acknowledgement}

This work has been sponsored by Mational Swedish Board for Technical Developcont (STU). Fruttful suggestions and discussions with Prop. A. Inove of the Institute for Mater lals Research. Tohoku University and Prof. H. Fredriksson of the Royel Institute of Technology. Stockhole, are gratefully acknowledged. 


\section{References}

(1) K. Enani and A. Menno, Mateil. Trans. 2 (1971) 1487.

(2) Y.K. Au and C. M. Wayaan, Scr. Metall., 6 (1972) 1209.

(3) A. Inove. H. Tomioks and T. Masumoto, Matall. Trans. i4 (1983) 1367.

(4) A. Inoue, H. Tontoka, T. Masunoto, J. Mater. Sel. 19 (1984) 3097.

(5) S. Furukawa, A. Inoue and T. Masumoto, Mater. Sc1. Eng., 98:2(1988). 515-518.

(6) P. Johansson, report Ho. IM-2398, (Oec. 1988). Internal report from the Swodish Institute for Metols Research, Stockholm.

(7) R. Ruhl, Materials Science Engineoring 1 (1967) 313-320.

(8) I. Onnaka, International Journal of Repid Solidification, I (1984-85) 219-236. 